\title{
Biyokömür; Tanımı, Kullanımı ve Tarım Topraklarındaki Etkileri
}

\section{Elif GÜNAL"' ${ }^{*}$, Halil ERDEM'}

\author{
' Gaziosmanpașa Üniversitesi, Ziraat Fakültesi, Toprak Bilimi ve Bitki Besleme Bölümü, 60240 Tokat
}

Öz: Biyokütlenin oksijenin sınırlı olduğu bir ortamda termo-kimyasal dönüșümü ișlemi ile elde edilen karbon (C) bakımından zengin katı materyaller biyokömür olarak tanımlanmaktadır. Biyokömürün toprak verimliliği ve bitki gelișimi üzerine etkisi, biyokömürün ve uygulanan toprağın özellikleri, uygulama dozu ve uygulanan ürünün isteklerinin karșlıklı etkileșimleri tarafından belirlenmektedir. Ancak, biyokömürün yüksek pH'sı, gözenekli yapısı ve yüksek yüzey yükü nedeni ile toprağın fiziksel, kimyasal ve biyolojik özellikleri üzerine doğrudan veya dolaylı yollarla etki ettiğini rapor eden çok sayıda araștırma yayınlanmıștır. Bunlara ilaveten biyokömürün yüksek yük yoğunluğu ve yüzey alanı ile fitotoksik organik molekülleri adsorbe edebilmesi ve toprak kökenli patojenleri baskılaması da bitkisel üretimdeki olumlu etkileri arasında sayılabilir. Bu derlemede, biyokömürün tarım arazilerindeki kullanımını özellikle de toprak verimliliği ve ürün verimini konu eden $5 \mathrm{I}$ adet araștırmanın dikkate değer bulguları özetlenerek karșılaștırıımıș ve tartıșılmıștır.

Anahtar Kelimeler: biyokömür, toprak verimliliği, besin elementi, bitki hastalığı, kireçleme etkisi

\section{Biochar; Definition, Utilization and Effects on Agricultural Soils}

\begin{abstract}
Carbon rich solid materials produced by thermo-chemical conversion of biomass in an oxygen limited environment is defined as biochar. The impact of biodiversity on soil fertility and plant growth is determined by the interactions among characteristics of biochars and amended soil, application rate and requirements of crops grown. However, many reports have been published indicating that biochar can directly or indirectly influence physical, chemical and biological properties of soils due to high $\mathrm{pH}$, porous structure and large surface charge. Ability to adsorb phytotoxic organic molecules with its high surface charge and surface area and to suppress soil-borne pathogens can be considered as positive effects of biochar on plant production. In this review, remarkable findings of 50 studies conducted on investigating the biochar use on agricultural fields particularly effects on soil fertility and crop productivity have been summarized, compared and discussed.
\end{abstract}

Keywords: biochar, soil fertility, nutrient efficiency, plant disease, liming effect

\section{GiRiș}

Modern tarımda birim alandan daha yüksek miktarda ürün alabilmenin en önemli șartlarından biri bitkinin gereksinim duyduğu besin elementlerinin gübre șeklinde ilave edilmesidir. Gübre uygulaması ile gübreleme yapılmayan koșullara kıyasla \%30 ile \%50 arasında verim artıșı sağlamak mümkün olsa da organik madde ilavesi olmadan kimyasal gübrelere uzun süre olan bağımlılık gübre kullanım etkinliğinin düșmesine ve çevre kirliliği sorunlarına neden olmaktadır (Chaudhary ve ark., 2017). Tarım arazilerinde uygulanan azotlu $(\mathrm{N})$ gübrelerin önemli bir kısmının yüzey akıșı, $\mathrm{NH} 3$ șeklinde volatilizasyonu, $\mathrm{NO}_{3}$ - șeklinde yıkanması ile bitkisel üretimde kullanılamadığı, yüzey ve yüzey altı sularında kirlenmeye neden olduğu bildirilmiștir (Tian ve ark., 2018). Bu nedenle, sürdürülebilir tarımsal üretim yapabilmek için toprağın organik maddesi ile temel besin elementlerinin biyolojik döngüsünü uygun bir seviyede tutmak çok önemlidir. Literatürde kompost, hayvan gübresi ve yeșil gübreleme gibi birçok uygulamanın mikroorganizma faaliyetlerini arttırdığı ve yetiștirilen ürünlerin besin gereksinimlerinin önemli bir kısmını karșıladıklarına dair araștırma raporları bulmak mümkündür. Ancak ilave edilen organik atıklar toprakta çok hızlı ayrıștıklarından dolayı bu katkı maddelerinin ömürleri ve etkileri oldukça kısadır (Naeem ve ark., 20I8).

Biyokütlenin yüksek sıcaklıkta ve oksijensiz ortamda ısıtılması (pirolizi) ile elde edilen biyokömür, bozulmaya karșı dirençli olan yapısı, yüksek spesifik yüzey alanı ve negatif yüzey yükü gibi özelliklerinden dolayı toprağın fiziksel, kimyasal ve biyolojik özelliklerini iyileștirebilecek ve bitkisel üretimin verimliliğini arttırabilecek bir katkı maddesi olarak düșünülmektedir (Madari ve ark., 2017; Zhang ve ark., 2017). Biyokömürün ılıman bölgelerde ve tropikal ekosistemlerde toprak kalitesini ve ürün verimliliğini arttırdığına dair raporlar yayınlanmaktadır (Güereña ve ark., 20I3). Biyokömürün toprağın verimliliğini arttırmak üzere kullanımına ait ilk bulgular ise Amazonlarda keșfedilen Terra Preta de Indio toprakları üzerinde yapılan çalıșmalara dayanmaktadır. Terra Pretalar kilometrelerce uzunluktaki koyu renkli ve verimli topraklardır (Kammann ve ark., 2016).

Global ölçekte bir meta analiz yapan Jeffery ve ark. (20I7), biyokömürün ılıman iklimlerde verim artıșına hemen hemen hiçbir etkisinin olmadığını ancak tropik iklime sahip bölgelerde ortalama \%25 oranında verim artıșı sağladığını belirtmișlerdir. Tropik bölgelerdeki toprakların pH'larının düșük olması (medyan $\mathrm{pH}=5.7$ ) ve yüksek ayrıșma ile birlikte verimlilik seviyelerinin düșük olması, yüksek pH'ya sahip biyokömürlerin (medyan $\mathrm{pH}=9.0$ ) uygulamalarına olumlu tepki vermelerinin gerekçesi olarak açıklanmıștır. Bunun aksine daha yüksek pH'ya (medyan $\mathrm{pH}=6.9$ ) sahip

Sorumlu Yazar: elifgunal@yahoo.com Bu çalıșma doktora tezi ürünüdür.

Geliș Tarihi: 14 Mart 2018

Kabul Tarihi: 6 Kasım 2018 
olan ılıman bölge topraklarının doğal olarak daha verimli olmalarının yanında yüksek miktarda gübreleme yapılıyor olmasının biyokömürün yaptığı katkıyı gölgelediği düșünülmektedir (Jeffery ve ark., 2017). Biyokömürün toprağın verimliliği üzerine olan etkisi, toprakta besin elementlerinin miktarı ve yarayıșlılığı (Lehmann ve ark., 2003) ve toprağın biyokimyasal özelliklerine olan (Luo ve $\mathrm{Gu}, 2016)$ etkisi ile ilișkilendirilmiștir. İlave edilen biyokömür özelliklerine de bağlı olmakla birlikte, toprakta su ve besin elementi tutumu veya mikrobiyal aktivite gibi özelliklere biyokömürün doğrudan etki ettiği düșünülmektedir (Atkinson ve ark., 20l0; Lehmann ve ark., 20II). Yüzey alanı ve $C$ içeriği oldukça yüksek, yapısı çok gözenekli ve çoğunlukla alkali karakterde olan biyokömürün toprağa uygulanması; toprağın organik madde içeriğinin yükselmesine (Liu ve erk., 2017) ve pH'nın artıșına (Chan ve ark., 2008; Gaskin ve ark., 2010; Laird ve ark., 2010) ve toprak mikroorganizmalarının çeșidi ve miktarının değișmesine (Gul ve ark., 20I5) neden olduğu bildirilmiștir. Bunun yanında biyokömür ilavesinin toprağın fiziksel özelliklerinden hacim ağırlığının düșmesine (Asai ve ark., 2009; Laird ve ark., 2010), toprak sıkıșmasının azalmasına (Olmo ve ark., 20I4; Liu ve ark., 2017), toprağın yüzey alanının (Lehmann ve ark., 20II) ve toplam gözenekliliğin artmasına (Githinji, 20।4), gözenek büyüklük dağılımının (Sun ve Lu, 2014) ve su tutma kapasitesinin artmasına (Akhtar ve ark., 20I5) neden olduğu da rapor edilmiștir. Bitkinin gelișimi için ortamın daha uygun hale gelmesi ise toprak verimliliğinin artması, bitkinin daha iyi gelișmesi ve nihayetinde bitkisel üretim miktarının önemli miktarda artmasına neden olmaktadır.

\section{BIYOÇAR UYGULAMALARININ BITKI GELIȘiMiNE VE VERIMLiLiĞE ETKILERi}

Biyokömür uygulamasının toprağın verimliliğine, bitki gelișimine ve ürün verimine etkileri; ürün çeșidi, biyokömür uygulama oranları ve biyokömürün özellikleri ile bitki yetișme koșulları, edafik faktörler, kullanılan kimyasal gübreler ve incelenen yıla bağlı olarak değișmektedir (Jeffery ve ark., 20ll; Zhang ve ark., 20l2). Biyokömürün çeșidi, üretim koșulları, uygulanan toprağın özellikleri ve denemenin yürütüldüğü ortamın koșullarına bağlı olarak biyokömür uygulamalarının bitkisel üretime ve ürünlerin performansına olan etkisinin olumlu olduğunu rapor eden çalıșmalar olduğu gibi (Chan ve ark., 2007; Asai ve ark., 2009; Lin ve ark., 20I5; Liu ve ark., 2017), biyokömürün etkisinin önemsiz (Nelissen ve ark., 2015; Subedi ve ark., 2016; Hansen ve ark., 2017) ve hatta olumsuz (Gaskin ve ark., 2010; Lin ve ark., 20I5; Nelissen ve ark., 2015) olduğunu bildiren araștırma raporları da yayınlanmıștır. Bunlara ilaveten biyokömürün topraktaki fitotoksik organik molekülleri adsorbe edebilmesi (Oleszczuk ve ark., 20I2) ve toprak kökenli patojenleri baskılaması (Eo ve ark., 2018) da bitki gelișimine olumlu etkileri olarak bildirilmiștir.
Biyokömürün ürün verimine olumsuz veya nötr etkisiyle çoğunlukla tropik bölgelerde karșılașıldığını rapor eden Jeffery ve ark. (20I7), yüksek pH'sı nedeni ile biyokömürün bu topraklarda fazla kireçleme etkisi ile pH'nın gereğinden fazla yükselmesine neden olduğunu bununda mangan, demir, bor ve fosfor (P) gibi besin elementlerinin alımını engelleyebileceğini bildirmișlerdir. Bu etkilerin yer aldığı araștırma sonuçlarına ait ilgi çekici örnekler așağıda yer almaktadır.

Herhangi bir biyokömür çeșidinin toprak özelliklerine etkisi, uygulanan biyokömür materyalinin karakteristikleri, uygulama yapılan toprağın özellikleri ve uygulama yapılan bitkinin çeșidine bağlı olarak büyük değișkenlik gösterebilir (Prapagdee ve Tawinteung, 2017). İki farklı ürün için aynı toprakta kullanılan biyokömürün ürün gelișimi performansı farklı olabilir. Lin ve ark. (20I5), tınlı bir toprağa ilave edilen $16 \mathrm{Mg} \mathrm{ha-1}$ mısır koçanı biyokömürünün buğday verimini arttırdığını rapor ederken, benzer bir uygulamanın soya fasulyesi gelișimine etkisi olmadığını görmüșlerdir. Çin'in İç Moğolistan bölgesinde Kubuqi ve Pakistan'ın Thar Çöllerinde kumlu topraklara çam talașının 400 `C'de pirolizi ile elde ettikleri biyokömürleri uygulayan Laghari ve ark. (20।5), çöl topraklarının su tutma kapasitesinin arttığını, hidrolik iletkenliğinin azaldığını, toplam C, potasyum (K), P ve kalsiyum (Ca) konsantrasyonlarının arttığını ve pH'nın önemli düzeyde azaldığını bildirmișlerdir. Toprak özelliklerindeki bu iyileșmenin ise sorgumun kuru madde miktarında Kubuqi'de \%18 ve Thar çölü topraklarında \%22 oranında artıșa neden olduğunu rapor etmișlerdir.

Biyokömür ilave edilen topraklarda bitki gelișiminin artması, besin elementi kullanım etkinliğinin iyileșmesi, toprağın kimyasal ve mikrobiyal özelliklerindeki pozitif etkisinin yanında besin elementlerinin yıkanmasının azaltılması ile de ilișkilidir (Gul ve ark., 20I5). Lehmann ve ark. (2003)'da biyokömür uygulamalarının verimlilik üzerine etkisini biyokömürün yüksek su ve besin elementi tutma yeteneği nedeni ile gübrelerle uygulanan besin elementleri yıkanmasını azaltması ve gübre kullanım etkinliğini arttırması ile açıklamıșlardır.

Yeni Zellanda'da okaliptus, mısır koçanı, taze çam ve söğüt kullanarak $550{ }^{\circ} \mathrm{C}^{\prime}$ de üretilen biyokömürler, ince kumlu ve ince tınlı iki tekstüre sahip toprakta mısırın çimlenmesi üzerine etkilerini görmek amacı ile kullanılmıștır (Free ve ark., 2010). Uygulamada $20 \mathrm{~cm}$ derinliğe olacak șeklide 0 , 2.5, 5.0 ve 10 ton ha-1 düzeyindeki biyokömürler uygulanmıștır. Araștırmacılar çalıșma sonunda, farklı biyokömürlerin ve dozlarının mısır tohumunun çimlenmesine kontrole göre önemli düzeyde etki ettiğini belirtmiș ve biyokömürün toprakta C'un depolanması ve toprağın kalitesinin arttırılması adına oldukça önemli etkileri olduğunu rapor etmișlerdir.

Amerika Birleșik Devletleri'nin güney doğusunda yer alan organik madde içeriği ve verimliliği düșük Ultisol 
(Kandiudults)'lere uygulanan fıstık kabuğu ve çam atıklarından üretilen biyokömürün topraktaki besin elementi verimine etkileri, Gaskin ve ark. (2010) tarafından iki yetiștirme sezonu boyunca araștırılmıștır. Araștırmacılar biyokömür dozlarını 0 , II ve $22 \mathrm{Mg}$ ha-l olacak șekilde düzenleyerek biyokömürü N'lu gübre ile ve N'lu gübre kullanılmadan uygulamıșlardır. Bu çalıșmada, artan çam biyokömürü uygulama dozunun toprağın pH'sını düșürdüğü ve Ca'un yarayıșlılığını arttırdığı görülmüștür. Araștırmanın ilk yılında artan çam biyokömür dozu ile mısır veriminin azaldığı görülmüștür. Fıstık kabuğu uygulamasının toprağın ilk $15 \mathrm{~cm}$ derinliğindeki $\mathrm{Ca}, \mathrm{Mg}$ ve $\mathrm{K}$ seviyesini arttırdığı bildirilirken en yüksek biyokömür dozunun $(22 \mathrm{Mg} \mathrm{ha-1}=$ $418 \mathrm{~kg} \mathrm{ha-1)}$ verimde azalmaya neden olduğu rapor edilmiștir. Diğer yandan, Hansen ve ark. (2017) gazlaștırma ile elde edilen biyokömür uygulamasının toprak organik C içeriğini önemli düzeyde arttırmadığını bildirirken kıșlık buğday ve kıșlık kolza verimlerine de önemli bir etkisinin olmadığını bildirmișlerdir.

Bir kısım araștırmalarda, biyokömürün sadece besin elementinin sınırlı olduğu koșullarda gübre olarak görev yapabileceği ve kök bölgesindeki mikroorganizma topluluğunu değiștirerek bitki gelișimini teșvik edebileceği ifade edilmiștir (De Tender ve ark., 2016). Biyokömür ilavesinin ürün verimliliğine olumlu etkisi uygun fiziksel, kimyasal ve biyolojik toprak ortamı ve besin elementi yarayıșlılığı ile toprak su yarayıșlılığının iyileșmesine bağlamıșlardır (Lehmann ve ark., 20II; Novak ve ark., 2016). Bitki gelișimine en olumlu etkinin ise $\mathrm{pH}$ 'sı en düșük olan biyokömür ilavesi ile yapıldığı görülmüș ve bu nedenle de piroliz koșullarının pH'yı yükseltmeyecek șekilde ayarlanmasının önemi vurgulanmıștır (Taghizadeh-Toosi ve ark., 20I2). Subedi ve ark. (2016), tavuk gübresi (400 ve 600 ${ }^{\circ} \mathrm{C}$ ), domuz gübresi $\left(400\right.$ ve $600{ }^{\circ} \mathrm{C}$ ) ve kivi ağacı budama atıklarından $\left(1000{ }^{\circ} \mathrm{C}\right)$ üretilen biyokömürleri siltli tın ve kumlu tekstüre sahip iki ayrı toprağa uygulamıș ve çavdar gelișimi ile toprağın kimyasal ve biyolojik özelliklerine etkilerini araștırmıșlardır. Saksı denemesi sonunda, düșük sıcaklıkta $\left(400{ }^{\circ} \mathrm{C}\right)$ hayvan gübresinden elde edilen biyokömürün hem sap hem de kök kuru madde verimini kontrole göre önemli düzeyde arttırdığı belirlenmiștir. Bunun yanında $600{ }^{\circ} \mathrm{C}$ 'de üretilen hayvan gübresi biyokömürleri ile odun biyokömürünün ne sap ne de kök kuru madde verimine etkisi olmadığı bildirilmiștir. Kontrole kıyasla en yüksek sap kuru madde artıșı (\%50,I) tavuk gübresinden $400{ }^{\circ} \mathrm{C}$ 'de üretilen biyokömür ile siltli tın toprakta elde edilmiștir. Aynı biyokömürün kök kuru madde miktarında ise \%/27.2'lik bir artıșa neden olduğu görülmüștür. Biyokömürün $\mathrm{N}$ içeriğinin hem sap kuru madde (siltli tın için korelasyon katsayısı $(r)=0.78$, kumlu için $r=0.61$ ) hem de kök kuru madde verimi (siltli tın için $r$ $=0.82$, kumlu için $r=0.59$ ) ile pozitif bir korelasyonu olduğu görülmüștür.

Piroliz esnasında sıcaklık $200{ }^{\circ} \mathrm{C}$ 'ye yaklaștığında hammadde de bulunan N'un uçucu gazlara dönüștüğü bildirilmekte içeriğine, mısırın (Zea Mays L.) beslenme durumuna ve

olup, üretim sıcaklığına ve hammaddenin $\mathrm{N}$ içeriğine bağlı olarak biyokömürün $\mathrm{N}$ konsantrasyonu \%0.2 ile \%7.8 arasında olarak rapor edilmiștir (Chan ve ark., 2007). Hammaddenin piroliz edildiği sıcaklık düștüğünde ekstrakte edilebilir $\mathrm{NH}_{4}$ miktarının arttığı (Gundale ve Deluca, 2006) bu nedenle düșük sıcaklıkta üretilen biyokömür ilavesinin topraktaki toplam $\mathrm{N}$ miktarının artıșına neden olduğu ve bitki gelișimi için gerekli olan N'un bir kısmını karșılayabileceği bildirilmiștir (Luo ve ark., 20l4). Biyokömür, kompost ve mineral gübreleri birlikte uygulayan Naeem ve ark. (20/8)'da artan sap ve dane verimi ile $\mathrm{N}$ konsantrasyonunun direk olarak biyokömür ve kompost ile katılan $\mathrm{N}$ olduğunu belirtmișlerdir. Özellikle düșük sıcaklıkta üretilen biyokömürlerin $\left(400{ }^{\circ} \mathrm{C}\right)$ tınlı kum ve kumlu tekstüre sahip iki ayrı toprakta da çavdarın sap ve kök kuru madde verimlerinde önemli düzeyde artıșa neden olmasını Subedi ve ark. (2016), i.) biyokömür ile toprağa direk besin elementi katılması (Lehmann ve ark., 2003), ii.) biyokömür ilave edilen topraklarda $\mathrm{N}$ mineralizasyonunun daha da artmış olması (Ameloot ve ark., 20I5), iii.) toprak pH'sının artıșı ile birlikte toprak-biyokömür-P'unun yarayıșlılığının artması (siltli tınlı toprakta) ve bunun ardından $P$ alımının artması (Wang ve ark., 20I2), ve iv.) toprak mikroorganizmalarının aktivitelerine bağlı olarak S'ün biyojeokimyasal döngüsünün gelișmesi (Lehmann ve ark., 20l I; Subedi ve ark., 2016) ile açıklamıșlardır. Toprağa uygulanan biyokömürün P'un yarayıșlılığını arttırdığını bildiren çok sayıda çalıșma mevcuttur (Chan ve ark., 2007; Atkinson ve ark., 20I0; Hossain ve ark., 20II). Fosfor yarayıșlılığının artmasının nedenlerinin; toprak pH'sındaki değișim, P'un diğer katyonlar ile olan etkileșimi ve anyon değișimi yoluyla P tutunmasının artması olabileceği bildirilmiștir (Atkinson ve ark., 2006).

Üretildikleri biyokütlenin doğasına bağlı olarak, biyokömürler değișik oranlarda besin elementi içerebilmektedirler. Liu ve ark. (2017), toprağa uygulanan 48 ton ha-1 biyokömür ile $6 \mathrm{l} \mathrm{kg} \mathrm{ha-1} \mathrm{yarayıșlı} P$ ve $594 \mathrm{~kg}$ haI yarayıșlı K ilave edildiğini rapor etmișlerdir. Araștırmacılar, K'un buğday sapının gelișimi, selüloz olușumunu desteklemesi ve hücre duvarının kalınlașmasını sağladığından dolayı buğdayın vejetatif gelișimini arttırdığını bildirmișlerdir. Biyokömür uygulaması ile bitki boyu \%5, kardeșlenme sayısı $\% 19$, sap biyo kütlesi $\% 12$ ve kök biyokütlesi ise $\% 10$ oranında artmıștır. Ancak dane verimi, bașak sayısı ve her bașaktaki dane sayısı üzerine biyokömür uygulamasının önemli bir etki yapmadığı ifade edilmiștir. Elde edilen sonuç, topraktaki yarayıșlı $\mathrm{N}$ havuzu üzerine biyokömürün olumlu etkisinin olmadığının bir göstergesi olarak kabul edilmiștir. Liu ve ark. (20I7), biyokömürün kendi bașına biyo yarayıșlı bir $\mathrm{N}$ kaynağı olmadığını bunun nedeninin N'un piroliz esnasında piroller, imidazoller ve piridinler gibi heterosiklik bileșiklere dönüșmesi (Knicker, 2010) olduğunu belirtmișlerdir. Biyokömür uygulaması ile birlikte topraktaki 
N yarayıșılığının azalmasına yönelik farklı açıklamalar da yapılmıștır. Bu nedenlerin bazıları, (i) nitrifikasyon ve denitrifikasyon popülasyonunun artıșı ile birlikte $N$ yüzeyinde yüklü fonksiyonel grupların varlığında daha yüksek $\mathrm{N}$ adsorpsiyonu (Utomo ve ark., 20I2); (iv) biyokömürde bulunan yüksek $\mathrm{C}: \mathrm{N}$ oranına sahip kolay mineralize olabilen alifatik bileșenlerden dolayı $\mathrm{N}$ immobilizasyonunun artması (Deenik ve ark., 20l0); ve (v) biyokömürün organik maddenin mikroorganizmalara maruz kalmasını önlemesinden dolayı toprak organik N'unun mineralizasyonunun önlenmesi (Aguilar-Chavez ve ark., 20I2) șeklinde özetlenebilir.

Yarayıșlı besin elementi kapsamı düșük olmasına rağmen biyokömür uygulamalarından olumlu tepki alan araștırmacılar bunu toksinlerin nötralize edilmesine (Wardle ve ark., 1998), özellikle su tutma kapasitesi gibi toprak fiziksel özelliklerinin iyileștirilmesine (Carvalho ve ark., 2014) ve toprak sıkıșmasının azaltılmasına (Chan ve ark., 2008) olan etkileri ile ilișkilendirmișlerdir. Biyokömürün toprağın su tutma kapasitesine ve adsorpsiyon kapasitesine etkisini değerlendiren araștırmacılar, elektron mikroskobu ile yaptıkları incelemede bu etkilerin biyokömürün oldukça gözenekli olan yapısından kaynaklandığını rapor etmișlerdir (Ogawa ve ark., 2006; Yu ve ark., 2006). Abel ve ark. (20I3), kumlu topraklara ilave edilen biyokömürün toprağın hacim ağırlığını düșürdüğünü, toplam gözenekliliğini arttırdığını ve solma noktasında tutulan su miktarındaki artıșla beraber toprağın yarayıșlı su içeriğinin artıșına neden olduğunu bildirmișlerdir. Üretildiği materyal ve üretim koșullarına bağlı olmakla birlikte biyokömür materyalinin hacim ağırlığının $0.08 \mathrm{~g} \mathrm{~cm}^{-3}$ ile (Gundale ve DeLuca, 2006) $1.7 \mathrm{~g} \mathrm{~cm}^{-3}$ (Oberlin, 2002) arasında değiștiği rapor edilmiștir. Toprakların hacim ağırlığının $1.3 \mathrm{~g} \mathrm{~cm}^{-3}$ ile $2.0 \mathrm{~g}$ $\mathrm{cm}^{-3}$ arasında değiștiği dikkate alındığında, böylesine düșük hacim ağırlığına sahip bir materyalin ilavesi ile toprağın hacim ağırlığının da azalması beklenmektedir. Bu nedenle de yapılan birçok araștırmada (Laird ve ark., 2010; Pereiria ve ark., 20I2), ilave edilen biyokömür miktarının artıșı ile hacim ağırlığının azaldığı belirtilmiștir.

Mısır samanının $400{ }^{\circ} \mathrm{C}$ 'de pirolizi ile üretilen biyokömürün 20 ton ha-1 ve 30 ton ha-1 dozları ile mısır veriminin artıșı üst toprakta $(0-10 \mathrm{~cm})$ azalan hacim ağırlığı ve artan toplam gözeneklilikle birlikte tutulan yüksek nem içeriği ile ilișkilendirilmiștir (Xiao ve ark., 2016). Araștırmacılar ayrıca besin elementi durumunun iyileșmesinin kök gelișimini teșvik etmesi ile ince köklerin sayısının arttığını da belirterek bu durumun su adsorbsiyonunu iyileștirdiğini bildirmișlerdir. Bunun neticesi olarak biyokömür ilave edilen uygulamalarda buğdayın dane veriminin önemli düzeyde yükseldiği rapor edilmiștir. Üç yıllık çalıșma sonunda, 20 ve 30 ton ha-1 biyokömür uygulamalarında su kullanım etkinliği \%9.4 ve \%।2.3 oranında artarken dane dönüșümü ve tüketiminin artması, (ii) yükselen toprak pH'sı nedeniyle $\mathrm{NH}_{3}$ formunda volatilizasyon ile $\mathrm{N}$ kaybının artması, (Chen ve ark., 2013); (iii) biyokömür veriminin de kontrole kıyasla \%।0.2 ve \%।4.2 oranında arttığı belirlenmiștir (Xiao ve ark., 20I6).

Bugüne kadar biyokömür uygulamasının toprak verimliliği ve bitki gelișimine etkisi çoğunlukla bir kez biyokömür uygulaması șeklinde çalıșılmıș ve raporlanmıștır. Farklı üretim sezonlarında üç yıl ardıșık șekilde biyokömür uygulamasının pamuk verimine ve pamuğun lif kalitesine etkilerini araștıran Tian ve ark. (20I8), siltli tın tekstürlü bir toprakta biyokömür uygulamasının pamuk gelișimi, toprak verimliliği ve $N$ tutunmasını olumlu etkilediğini bildirmișlerdir. Pamuk verimi ve lif kalitesine en yüksek etkinin biyokömür uygulama dozu ve zamanı ile büyük oranda değișim gösterdiğini bildiren Tian ve ark. (2018), en yüksek verimi her üretim sezonunda en yüksek biyokömür dozu (20 t ha-1) uygulaması ile elde etmișlerdir. Biyokömür uygulamasının ilk $20 \mathrm{~cm}$ derinlikteki organik $\mathrm{C}$, toplam $\mathrm{N}$, $\mathrm{NO}_{3}-\mathrm{N}, \mathrm{NH}_{4}{ }^{-}-\mathrm{N}$ ve yarayıșlı $\mathrm{K}$ içeriklerinin önemli miktarda artıșına neden olduğunu bildiren araștırmacılar, pamuk lif verimini kontrole kıyasla ilk yıl \%8.0 ile \%।5.8, ikinci yıl \%9.3 ile \%।3.9 ve üçüncü yıl ise \%9.2 ile \%2I.9 arasında yüksek bulunmuștur.

\section{BIYOÇARIN BITKI HASTALIKLARINA ETKILERİ}

Biyokömür ilavesinin toprağın bitki gelișim ortamını iyileștirmesi ve hastalıkları baskılayarak bitki performansını arttırdığı ve bitki gelișimini teșvik ettiği bildirilmektedir (Jeffery ve ark., 20II; Kolton ve ark., 2017). De Tender ve ark. (20/6), iki farklı üretim sisteminde, biyokömürün toprak ve substratın fiziko-kimyasal özellikleri, bitki gelișimi, hastalık hassasiyeti ve rizosfer mikrobiyolojisi üzerine etkileri çalıșmıșlardır. Araștırmacılar çilek yetiștirilen peat ortamına meșe fıstığının $650{ }^{\circ} \mathrm{C}$ 'de pirolizi ile elde edilen \%3’lük biyokömür ilavesinin i.) daha yüksek taze (\%।I6.5 artıș) ve kuru bitki ağırlığına (\%।I4.3 arțș), ii.) hem yapraklarında hem de meyvede mantar patojeni Botrytis cinera'ye daha düșük hassasiyete ve iii.) rizosfer mikrobiyolojisinde değișime yol açtığını bildirmișlerdir. Çeltik kavuzundan üretilen biyokömürün jinseng bitkisi (Panax ginseng) ve toprak organizmalarının (Cylindrocarpon destructans ve Fusarium solani)'nin neden olduğu kök çürüklüğü üzerine etkisini araștıran Eo ve ark. (20/8), biyokömür uygulanan topraklarda biyokömür uygulanmayanlara kıyasla patojenik mantar olușumunun bastırıldığını rapor etmișlerdir. Çeltik biyokömürünün 5.2 $\mathrm{Mg} \mathrm{ha}{ }^{-1}$ uygulandığı topraklarda mantar nematodlarının çok yoğun olduğunu tespit eden Eo ve ark. (2018), mantar nematodlarının patojenik mantarlarla beslenmesinin mantar popülasyonunu bastırdığını belirtmișlerdir.

Rizosfere yapılan biyokömür ilavesi bakteri çeșitliliğine neden olurken rizosfer bölgesinde yer alan mikroorganizmaların aktivitelerinde de önemli bir değișime yol açtığı belirlenmiștir. Kök bölgesindeki etkisinin yanında, yaprak mantar patojenlerine karșı etkili olabilecek çok çeșitli biyokömürlerin olduğu da rapor edilmiștir. Biyokömür 
toprağa uygulandığında domates ve biber bitkilerinin Botrytis cinera ve Oidiopsis sicula'ya karșı daha az hassas hale geldikleri görülmüștür (Elad ve ark., 2010). Benzer șekilde substrata biyokömür ilavesinin çilek bitkisinin Botrytis cinera, Colletotrichum acutatum ve Podosphaera apahanis'in neden olduğu 3 yaprak hastalığının șiddetini azalttığı da

\section{SONUÇ}

Dünyanın farklı yerlerinde çeșitli topraklarda yapılan çalıșmaların birçoğunda biyokömürün bitki gelișimine etkisi genelde sadece biyokömür kullanılarak gerçekleștirilmektedir. Biyokömürün besin elementi kapsamı piroliz sıcaklığı ve hammaddesine bağıı olarak büyük değișkenlik gösterdiğinden bir gübre olarak tavsiye edilmeleri mümkün değildir. Ancak yapılan çalıșmaların ortak noktası biyokömürün toprağın hacim ağırlığının düșmesine, su tutma kapasitesinin iyileșmesine ve besin elementlerinin yıkanmasının azaltılmasına olumlu katkı yapmasıdır. Bu nedenle, biyokömür gübre olmaktan ziyade bitki gelișim ortamının iyileșmesini sağlayan bir katkı maddesi olarak düșünülmelidir. Son dönemlerde sınırlı da olsa gerçekleștirilen biyokömürün diğer organik katkı maddeleri ve mineral gübreler ile birlikte uygulanmasına yönelik araștırmalara gereksinim duyulmaktadır. Biyokömürün topraktaki besin elementlerinin kullanım etkinliğini arttırması dolaylı da olsa bitki gelișimi ve toprak verimliliğini olumlu etkileyeceğinden bu konuda yapılan araștırma sonuçlarının uygulayıcılar için aydınlatıcı olması beklenmektedir.

Sıcaklık artıșı ile biyokömürün pH'sının artması ve üretilen biyokömürlerin büyük bir kısmının alkali karakterde olması, bugüne kadar yapılan çalıșmaların büyük bir kısmının asit karakterli topraklarda olmasına neden olmuștur. Kireçleme etkisi ile toprağın pH'sının yükselmesine katkı vermesi besin elementlerinin yarayıșlılığının artmasına neden olduğu için birçok araștırmanın konusu olmuștur. Ancak ülkemiz topraklarının alkali karakterde olduğunu da göz önüne alarak, farklı toprak ordoları ve iklim özellikleri altında biyokömür konusunda yapılacak yeni çalıșmalara gereksinim olduğu söylenebilir. Çoğunlukla yarı kurak bir iklime sahip olan ülkemiz topraklarının organik madde bakımından yetersiz olduğu ve bu nedenle așınmaya karșı hassas olduğundan șiddetli su ve rüzgar erozyonuna maruz kaldığı bilinmektedir. Bu nedenle arazilerimizin üretkenlikleri düșmekte ve ihtiyacımız olan gıdayı üretemez konuma gelmekteyiz. Tarım arazilerimizde üretim sonrası, șehirlerin park bahçe bakım atıkları ve gıda sanayiindeki atıkların biyokömüre dönüștürülmesi ile ilgili çalıșmalar, bu atıkların çevreye faydalı ürünler haline gelmesini sağlayacak ve ülkemiz için önemli bir katma değer olușturacaktır.

\section{KAYNAKLAR}

Abel S, Peters A, Trinks S, Schonsky $H$, Facklam M, Wessolek G (20I3) Impact of biochar and hydrochar addition on water retention and water repellency of sandy soil. Geoderma 202: 183-191.

Aguilar-Chavez A, Díaz-Rojas M, del Rosario C, ArdenasAquino M, Dendooven L, Luna-Guido M, (20/2) Greenhouse gas emissions from a wastewater sludge amended soil cultivated with wheat (Triticum spp. L.) as affected by different application rates of charcoal. Soil Biology and Biochemistry 52: 90e95. bildirilmiștir (Harel ve ark., 20I2). Biyokömür ilavesi ile kök bölgesinde artan bakteri çeșitliliği ve popülasyonun karbonhidrat ve fenolik bileșiklerin tüketimini arttırdığı ve bu durumun fenolik bileșikleri parçalayan bakterileri teșvik ettiği rapor edilmiștir (Kolton ve ark., 2017).

Akhtar SS, Andersen MN, Naveed M, Zahir ZA, Liu F (2015) Interactive effect of biochar and plant growthpromoting bacterial endophytes on ameliorating salinity stress in maize. Functional Plant Biology 42: 770-78I.

Ameloot N, Sleutel S, Das KC, Kanagaratnam J, Neve S (20I5) Biochar amendment to soils with contrasting organic matter level: effects on $\mathrm{N}$ mineralization and biological soil properties. Gcb Bioenergy 7(I): I35-I44.

Asai H, Samson BK, Stephan HM, Songyikhangsuthor K, Homma K, Kiyono Y, Horie T (2009) Biochar amendment techniques for upland rice production in Northern Laos: I. Soil physical properties, leaf SPAD and grain yield. Field Crops Res II I (I): 8I-84.

Atkinson C, Fitzgerald J, Hipps N (2010) Potential mechanisms for achieving agricultural benefits from biochar application to temperate soils: A review. Plant Soil 337: I-18.

Carvalho de Melo MT, Maia ADHN, Madari BE, Bastiaans L, Van Oort PAJ, Heinemann AB, ... \& Meinke H (20l4) Biochar increases plant-available water in a sandy loam soil under an aerobic rice crop system. Solid Earth 5(2): 939-952.

Chaudhary S, Dheri GS, Brar BS (2017) Long-term effects of NPK fertilizers and organic manures on carbon stabilization and management index under rice-wheat cropping system. Soil Tillage \& Research 166: 59-66.

Chan KY, Dorahy C, Tyler S (2007) Determining the agronomic value of composts produced from garden organics from metropolitan areas of New South Wales, Australia. Animal Production Science 47(II): 13771382.

Chan KY, Van Zwieten L, Meszaros I, Downie A, Joseph S (2008) Agronomic values of green waste biochar as a soil amendment. Soil Research 45(8): 629-634.

Chen J, Liu X, Zheng J, Zhang B, Lu H, Chi Z, ... \& Wang J (20I3) Biochar soil amendment increased bacterial but decreased fungal gene abundance with shifts in community structure in a slightly acid rice paddy from Southwest China. Applied Soil Ecology 7I: 33-44.

Deenik JL, McClellan T, Uehara G, Antal MJ, Campbell S (2010) Charcoal volatile matter content influences plant growth and soil nitrogen transformations. Soil Science Society of America Journal 74: 1259-1270.

De Tender CA, Debode I, Vandecasteele B, D'Hose T, Cremelie P, Haegeman A, ... \& Maes $M$ (2016) Biological, physicochemical and plant health responses in lettuce and strawberry in soil or peat amended with biochar. Applied Soil Ecology 107: I-I2.

Eo J, Park KC, Kim MH, Kwon SI, Song YJ (2018) Effects of rice husk and rice husk biochar on root rot disease of ginseng (Panax ginseng) and on soil organisms. Biological Agriculture \& Horticulture 34(I): 27-39.

Free HF, McGill CR, Rowarth JS, Hedley MJ (2010) The effect of biochars on maize (Zea mays) germination. New Zealand Journal of Agricultural Research 53(I): I 4. 
Jeffery S, Verheijen FG, Van Der Velde $M$, Bastos AC (20II) A quantitative review of the effects of biochar application to soils on crop productivity using metaanalysis. Agriculture, Ecosystems \& Environment I44(I): 175-187.

Jeffery S, Abalos D, Prodana M, Bastos AC, Van Groenigen JW, Hungate BA, Verheijen F (2017) Biochar boosts tropical but not temperate crop yields. Environmental Research Letters: I2(5), 05300 I.

Gaskin JW, Speir RA, Harris K, Das KC, Lee RD, Morris LA, Fisher DS (20I0) Effect of peanut hull and pine chip biochar on soil nutrients, corn nutrient status, and yield. Agronomy Journal 102(2): 623-633.

Githinji L (2014) Effect of biochar application rate on soil physical and hydraulic properties of a sandy loam. Archives of Agronomy and Soil Science 60(4): 457-470.

Güereña D, Lehmann J, Hanley K, Enders A, Hyland C, Riha $S$ (2013) Nitrogen dynamics following field application of biochar in a temperate North American maize-based production system. Plant and Soil 365(I-2): 239-254.

Gul S, Whalen JK, Thomas BW, Sachdeva V, Deng H (20I5) Physico-chemical properties and microbial responses in biochar-amended soils: mechanisms and future directions. Agriculture, Ecosystems \& Environment 206: 46-59.

Gundale M, DeLuca T (2006) Temperature and source material influence ecological attributes of ponderosa pine and Douglas-fir charcoal. Forest Ecology and Management 23I(I-3): 86-93.

Harel YM, Elad Y, Rav-David D, Borenstein M, Shulchani R, Lew B, Graber ER (20I2) Biochar mediates systemic response of strawberry to foliar fungal pathogens. Plant and Soil 357(1-2): 245-257.

Hossain MK, Strezov V, Chan KY, Ziolkowski A, Nelson PF (201I) Influence of pyrolysis temperature on production and nutrient properties of wastewater sludge biochar. Journal of Environmental Management 92: 223-228.

Kammann C, Ippolito J, Hagemann N, Borchard N, Cayuela ML, Estavillo JM, ... \& Rasse D (2017) Biochar as a tool to reduce the agricultural greenhouse-gas burdenknowns, unknowns and future research needs. Journal of Environmental Engineering and Landscape Management, 25(2), I|4-I39.

Knicker H (2010) Black nitrogen'ean important fraction in determining the recalcitrance of charcoal. Organic Geochemistry 41: 947e950.

Kolton M, Graber ER, Tsehansky L, Elad Y, Cytryn E (2017) Biochar-stimulated plant performance is strongly linked to microbial diversity and metabolic potential in the rhizosphere. New Phytologist 2 I3(3): I 393-I 404.

Laghari M, Mirjat MS, Hu Z, Fazal S, Xiao B, Hu M, Chen Z, Guo D (20I5) Effects of biochar application rate on sandy desert soil properties and sorghum growth. Catena (I35): 313-320.

Laird D, Fleming P, Davis D, Horton R, Wang B, Karlen D (2010) Impact of biochar amendments on the quality of a typical midwestern agricultural soil. Geoderma 158(34): 443-449.
Lehmann J, da Silva Jr, JP, Steiner C, Nehls T, Zech W, Glaser B (2003) Nutrient availability and leaching in an archaeological Anthrosol and a Ferralsol of the Central Amazon basin: fertilizer, manure and charcoal amendments, Plant and Soil 249: 343-357.

Lehmann J, Rillig MC, Thies J, Masiello CA, Hockaday WC, Crowley D (20II) Biochar effects on soil biota-a review. Soil Biology and Biochemistry 43(9): 1812-1836.

Lin XW, Zie ZB, Zheng IY, Liu Q, Bei QC, Zhu IG, (20I5) Effects of biochar application on greenhouse gas emissions, carbon sequestration and crop growth in coastal saline soil. European Journal of Soil Science 66: 329-338.

Liu Q, Liu B, Zhang Y, Lin Z, Zhu T, Sun R, ... Lin X (2017) Can biochar alleviate soil compaction stress on wheat growth and mitigate soil $\mathrm{N}_{2} \mathrm{O}$ emissions? Soil Biology and Biochemistry 104: 8-17.

Luo L, Gu ID (2016) Alteration of extracellular enzyme activity and microbial abundance by biochar addition: Implication for carbon sequestration in subtropical mangrove sediment. Journal of Environmental Management 182: 29-36.

Madari BE, Silva MA, Carvalho MT, Maia AH, Petter FA, Santos JL, ... \& Zeviani WM (2017) Properties of a sandy clay loam Haplic Ferralsol and soybean grain yield in a five-year field trial as affected by biochar amendment. Geoderma 305: 100-II2.

Naeem MA, Khalid M, Aon M, Abbas G, Amjad M, Murtaza B, Khan WUD, Ahmad N (2018) Combined application of biochar with compost and fertilizer improves soil properties and grain yield of maize. Journal of Plant Nutrition 4I(I): I I2-I22.

Nelissen V, Ruysschaert G, Manka'Abusi D, D'Hose T, De Beuf K, Al-Barri B, Boeckx P (20I5) Impact of a woody biochar on properties of a sandy loam soil and spring barley during a two-year field experiment. European Journal of Agronomy 62: 65-78.

Novak JM, Ippolito JA, Lentz RD, Spokas KA, Bolster CH, Sistani K, ... Johnson MG (2016) Soil health, crop productivity, microbial transport, and mine spoil response to biochars. BioEnergy Research 9(2): 454464.

Oberlin A (2002) Pyrocarbons. Carbon 40(I): 7-24.

Ogawa M, Okimori Y, Takahashi F (2006) Carbon sequestration by carbonization of biomass and forestation: three case studies. Mitigation and Adaptation Strategies for Global Change I I: 429-444.

Oleszczuk P, Rycaj M, Lehmann J, Cornelissen G (20I2). Influence of activated carbon and biochar on phytotoxicity of air-dried sewage sludges to Lepidium sativum. Ecotoxicol. Environ. Saf. 80: 321-326.

Olmo M, Alburquerque JA, Barrón V, Del Campillo MC, Gallardo A, Fuentes M, Villar R (2014) Wheat growth and yield responses to biochar addition under Mediterranean climate conditions. Biology and Fertility of Soils 50(8): I I77-I I87.

Prapagdee S, Tawinteung N (2017) Effects of biochar on enhanced nutrient use efficiency of green bean, Vigna radiata L. Environmental Science and Pollution Research 24(10): 9460-9467. 
Subedi R, Taupe N, Pelissetti S, Petruzzelli L, Bertora C, Leahy JJ, Grignani C (2016) Greenhouse gas emissions and soil properties following amendment with manurederived biochars: influence of pyrolysis temperature and feedstock type. Journal of Environmental Management 166: 73-83.

Sun F, Lu S (2014) Biochars improve aggregate stability, water retention, and pore-space properties of clayey soil. Journal of Plant Nutrition and Soil Science 177(I): 26-33.

Tian X, Li C, Zhang M, Wan Y, Xie Z, Chen B, Li W (20I8) Biochar derived from corn straw affected availability and distribution of soil nutrients and cotton yield. PloS One I3(I): e0189924, I-I9.

Wardle DA, Zackrisson O, Nilsson MC (1998) The charcoal effect in Boreal forests: mechanisms and ecological consequences. Oecologia II5(3): 4I9-426.
Xiao Q, Zhu LX, Shen YF, Li SQ (2016) Sensitivity of soil water retention and availability to biochar addition in rainfed semi-arid farmland during a three-year field experiment. Field Crops Research 196: 284-293.

Yu XY, Ying GG, Kookana RS (2006) Sorption and Desorption Behaviors of Diuron in Soils Amended with Charcoal. Journal of Agricultural and Food Chemistry 54: 8545-8550.

Zhang AF, Bian RJ, Pan GX, Cui LQ, Hussain Q, Li LQ, Zweng J, Zheng X, Han X, Yu X (20I2) Effects of biochar amendment on soil quality, crop yield and greenhouse gas emission in a Chinese rice paddy: $A$ field study of 2 consecutive rice growing cycles. Field Crops Research 127: 153-160.

Zhang H, Yu X, jin Z, Zheng W, Zhai B, Li Z (2017) Improving grain yield and water use efficiency of winter wheat through a combination of manure and chemical nitrogen fertilizer on the Loess plateau, China. Journal of Soil Science and Plant Nutrition, 17(2): 46I-474. 
